\title{
Upper lobe cavity with intracavitary mass: an unexpected diagnosis
}

\author{
Jose Paxiuta, Maria João Lobão
}

Hospital de Cascais, Cascais, Portugal

\section{Correspondence to \\ Dr Jose Paxiuta,}

josepaxiuta@gmail.com

Accepted 16 December 2016

CrossMark

To cite: Paxiuta J,

Lobão MJ. BMJ Case Rep

Published online: [please

include Day Month Year]

doi:10.1136/bcr-2016-

218312

\section{DESCRIPTION}

A 77-year-old man, with diabetes and a smoker, with no other medical history, presented with cough with sputum and chest pain that had started 2 months earlier. He had no fever, no haemoptysis and no constitutional symptoms. He had a diminished murmur on right chest auscultation and reported of ipsilateral pleuritic pain. Routine blood tests were unremarkable. The chest X-ray (figure 1) showed a right upper lobe cavity with air-crescent in the periphery of a mass inside. It was better characterised with CT (figure 2) that showed an upper lobe cavitary mass with intracavitary content and adjacent pleural thickening. The mass showed no cleavage plane with the thoracic wall. Despite being highly suggestive of invasive aspergilosis (aspergiloma), ${ }^{1}{ }^{2}$ the differential diagnosis included other fungal infections, mycobacterial infection and neoplasm.

A tissue biopsy was obtained by CT-guided needle aspiration, and the histology revealed squamous-cell carcinoma of the lung. On the CT-staging, an adrenal gland nodule was found in relation with metastasis. The patient was referred to the oncologist for evaluation and adequate treatment approach.

Despite the highly suggestive diagnosis by the CT image and the lack of clinical signs and symptoms that frequently accompany a carcinoma of such dimensions, the definite diagnosis revealed the

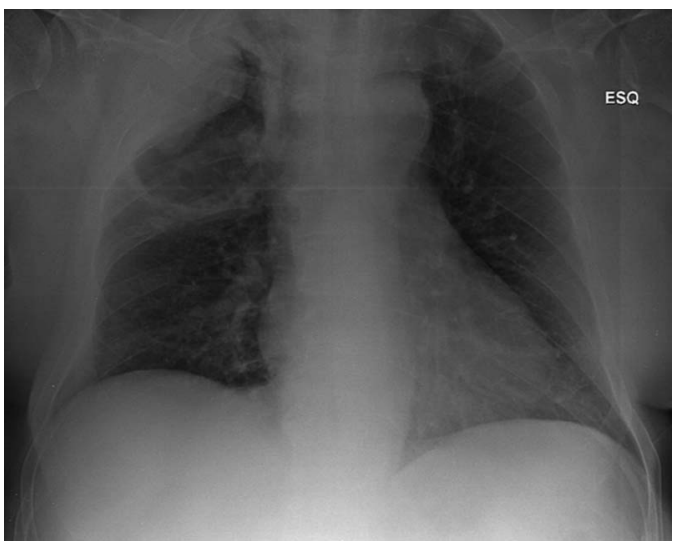

Figure 1 Chest X-ray.

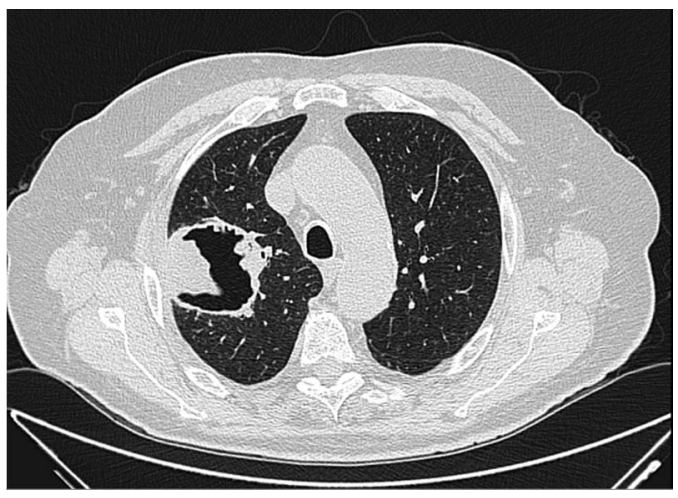

Figure 2 Chest CT scan.

importance of tissue biopsy in such rare presentation.

\section{Learning points}

- The lack of constitutional symptoms does not exclude the neoplastic aetiology in differential diagnosis.

- Despite the highly suggestive diagnosis by the $\mathrm{CT}$ image for aspergiloma, a tissue biopsy should be performed in all patients, if possible, given the fact that the management options are widely different.

Twitter Follow Jose Paxiuta at @josepaxiuta

Contributors JP was responsible for the elaboration of the manuscript, and MJL reviewed the manuscript.

Competing interests None declared.

Patient consent Obtained.

Provenance and peer review Not commissioned; externally peer reviewed.

\section{REFERENCES}

1 Kousha M, Tadi R, Soubani AO. Pulmonary aspergillosis: a clinical review. Eur Respir Rev 2011:20:156-74.

2 Patterson TF. Aspergillus species. In: Mandell GL, Bennett JE, Dolin $\mathrm{R}$, eds. Principles and practice of infectious diseases. 6th edn. New York: Elsevier/Churchill Livingstone, 2005:2958-73. 
Copyright 2017 BMJ Publishing Group. All rights reserved. For permission to reuse any of this content visit http://group.bmj.com/group/rights-licensing/permissions.

BMJ Case Report Fellows may re-use this article for personal use and teaching without any further permission.

Become a Fellow of BMJ Case Reports today and you can:

- Submit as many cases as you like

- Enjoy fast sympathetic peer review and rapid publication of accepted articles

- Access all the published articles

- Re-use any of the published material for personal use and teaching without further permission

For information on Institutional Fellowships contact consortiasales@bmjgroup.com

Visit casereports.bmj.com for more articles like this and to become a Fellow 